\title{
The Multiculturalism of Children's Literature: A Study about Children's Poems in Surakarta and Yogyakarta
}

\author{
A Sudigdo ${ }^{1,2}$, StY Slamet ${ }^{3}$, R Winarni ${ }^{3}$, dan N Ekowardani ${ }^{3}$ \\ ${ }^{1}$ Doctoral Student of Indonesia Language Education, Universitas Sebelas Maret Surakarta, \\ Indonesia \\ ${ }^{2}$ Faculty of Teacher Training and Education, Universitas Sarjanawiyata Tamansiswa \\ Yogyakarta, Indonesia \\ ${ }^{3}$ Faculty of Teacher Training and Education, Universitas Sebelas Maret Surakarta, Indonesia
}

anang.sudigdo@ustjogja.ac.id

\begin{abstract}
Multiculturalism substantially contains the values of cultural diversity which includes tolerance among religious groups. Internalizing the values of multiculturalism needs to be given to students from an early age. One of the efforts to internalize the values of multiculturalism is through literacy literature, namely writing poems with multiculturalism. This study discusses the students' understanding of the values of multiculturalism and tolerance for cultural diversity found in a collection of the students' poems. The focus of this study is multiculturalism and children's poems. This study aimed to explain the content of multiculturalism in the poems expressed by the elementary school students in Surakarta and Yogyakarta. This study used the qualitative research paradigm with content analysis method. The data in this study were the poems produced by the students. The data analysis technique used in this study was the interactive analysis technique consisting of data reduction, data display, and verification. To obtain data validity, data verification was done through data triangulation. The results showed that the poems made by elementary school students in Surakarta and Yogyakarta contained the values of multiculturalism. The themes of the poems are religion, cultural diversity and mutual respect. The students' works show their understanding of multiculturalism, so that they are expected to appreciate differences in religion, ethnicity, skin colour, race, culture, respect among the same, and uphold a sense of unity. Multiculturalism that is embedded in students early on is very helpful for them as a means of living side by side in diversity.
\end{abstract}

Keywords: Multiculturalism; Tolerance; Religion.

\section{INTRODUCTION}

Children's literature is a literary work that can be in the form of prose and poetry deliberately provided specifically for children to read. The presence of literature for children is intended for the children as readers to get entertainment that is both fun and beneficial for them. This is in line with the statement delivered [1] that children's literature is the literature that children can read. [2] added that children's literature is literature that reflects the feelings and experiences of children, which can be seen and understood through children's eyes. This is one of the 'basic 
capital' for children to understand reading in order to gain an understanding of the world and the lives they live. [3] argues that children's literature is a work that is "appropriate" to be read, heard, or consumed by children.

Children's literature is an imaginative creation form with exposure to certain languages that describe the imaginary world, present certain understandings and experiences, and contain certain aesthetic values that can be made by adults or children. Children's literature reflects more on children's feelings and experiences through children's views. Children have limits on vocabulary compared to adults. The vocabulary and diction that children have are not as rich and productive as those of adults. The students' creative reach and mind is limited according to their age. That is what becomes the characteristic and uniqueness of the children's work.

The presence of literature for children has a great psychological impact on the child's psyche. The experiences that a child has from childhood will affect his life and development. Childhood is a period of growth characterized by high curiosity. Children tend to be curious of a lot of good things related to themselves, their families, and the environment around them. They can accept all forms of information both logical and reasonable or not. This makes children often ask both their parents and teachers at school. High curiosity must be responded with an active attitude to provide information and internalize positive values expected to the children. Therefore, children's literature can be an appropriate means of meeting this need.

One variety of children's literature is poetry. Children's poetry is the poem about the world of children, both in factual and imaginative experience. The language is simple and easily understood by children. Nadeak [4] mentioned the characteristics that need to be considered in choosing children's poetry in elementary school are: (a) the content of the poem must be the experience of the child's world according to the age and level of development of the child's psyche; (b) the verses have appeal to children; (c) the verses must have the extrinsic beauty of language; and (d) the vocabulary is according to the child's world.

Children's poetry can be used as a means of internalizing the values of multiculturalism in students. That is through teaching poetry based on multiculturalism. The teaching process of writing poems to students can be done through learning in schools, the environment, and society. Through this learning, the students can know the values of multiculturalism which are then poured into poetry. Thus, literacy literature can be taught directly and the students can experience directly by writing children's poems based on multiculturalism.

Multicultural education is intuitively contained in article 4 [5] of the Constitution No. 20 of 2003 concerning the National Education System "Education is conducted in a democratic and just manner and is not discriminatory by upholding human rights, religious values, cultural values, and national plurality". The excerpt explains that tolerance values, religious values, cultural values and pluralism values need to be applied to educational institutions to teach the students about diversity that exists in Indonesia.

The students need to be taught the values of differences in religions, cultures, tribes, ethnicity, gender, social status, languages, and skin colours. They must be kept away from intolerance that can cause division. Internalizing the values of multiculturalism needs to be given to the students early so that they can understand the differences. These differences should be used as a rope of unity that can strengthen nationality. 
The presence of multiculturalism needs to be given to the students through poetry. Bennet formulates the notion of multiculturalism as thinking and acceptance of cultural diversity. In other words, multiculturalism is an understanding or belief that drives the acceptance of pluralism or cultural diversity as a cultural model that is present in contemporary social-cultural life [6]. Multiculturalism on the one hand is an understanding and the other is an approach, which offers a cultural paradigm to understand the differences that have existed in the midst of our society in the world[7].

Several important studies on multiculturalism in poetry have been conducted by [5] outlining the relevance of multiculturalism in the Ukrainian youth and the practice of Modern Ukrainian education. The researcher examined various artistic texts from novels and poems. The results of the study are the recommendations for schools in learning multicultural education; [8] outlines the multiculturalism of children's literature in literary works in Malaysia. Multicultural education for literature is very well studied by Malaysian children so that it can be implemented in diversity in the community; [9] examines the multicultural content contained in children's picture books. The book is an object for Korean and American children to learn about the diversity in their nation. Through the book, children are expected to have an attitude of tolerance and mutual respect among the nation's children; [10] conducted a study on the multicultural value of the text of Husni Djamaluddin's poetry using hermeneutic study; [11] conducted a study on the representation of Australian multiculturalism in the Wogs poem by Ania Walwicz. Referring to various studies that have been carried out, the study on multiculturalism in children's literature has been carried out. However, the study that has been conducted focuses on studying novel texts, textbooks and poems that only examine the content in the book that has been studied. This study focuses on studying the students' poetry works with multiculturalism obtained after participating in writing poems in class.

This study is an attempt to explain the content of multiculturalism in the poems expressed by the elementary school students in Surakarta and Yogyakarta as well as an effort to internalize the values of multiculturalism in students. The reality of poetry by students before learning to write poems based on multiculturalism is that they still have difficulties understanding the meaning of multiculturalism and pouring it into poems. During this time, the students in making poems have not included the values of multiculturalism. The benefit of the students' ability to write poems based on multiculturalism is that it can be embedded in their character. The benchmark for the students who have already understood the values of multiculturalism can be seen from the suitability of themes, sounds, words, and images. The students are able to express the values of multiculturalism in the poems that have been made. They can tolerate and respect cultural, religious, ethnic, skin colour, and racial differences. This can be seen from the results of the poems written by the students.

\section{METHOD}

This study was a qualitative descriptive study with content analysis method or content analysis.[12] defines analysis content focusing on valid data references from contents. This method WAS used to examine the contents of a document. The documents in this study were the multiculturalism-filled poems by the elementary school students in Surakarta and Yogyakarta. The analysis of the documents aimed to determine the students' understanding of the values of multiculturalism. The data in this study were the poems by the students containing multiculturalism. The data were collected using observation, interviews, documentation, 
reading, recording, and analysis of the students' works. The data were then validated using data and theoretical triangulation. The data analysis technique used in this study was the interactive analysis technique including data reduction, data display, and conclusion drawing/verification that occur simultaneously[13].

\section{RESULT AND DISCUSSION}

Based on the results of the analysis of the poems of the elementary school students in Surakarta and Yogyakarta, a number of values of multiculturalism can be found. A complete description of the values of multiculturalism can be seen in the following discussion.

\subsection{A Poem by M Yuma Briliant, International Islamic Elementary School Al Abidin Surakarta}

Hitam Putih

Black and White

\author{
Hai kawan \\ Tahukah kau hitam putih? \\ Warna? \\ Ya kawan ... itu warna \\ Warna kulit, \\ Warna kulit kita beda kawan \\ Maaf ... kau hitam \\ Karena Kau asal Papua \\ Sedangkan Aku? \\ Aku sedikit putih darimu \\ Karena aku asal Jawa \\ Kau dan Aku \\ Hitam dan putih \\ Papua dan Jawa \\ Tapi kita saling menghormati \\ Kita bersahabat \\ Dan kita adalah saudara \\ Kita Indonesia
}

\author{
Hi, friends \\ Do you know black and white? \\ Colours? \\ Yes, friends ... they're colours. \\ Skin colours, \\ Our skin colours are different, friends \\ Sorry ... you're black \\ Because You are from Papua \\ While I? \\ I'm a little whiter than you \\ Because I'm from Java \\ You and I \\ Black and white \\ Papua and Java \\ But we respect each other \\ We are friends \\ And we are brothers \\ We are Indonesia
}

The poem entitled Hitam Putih above is full of multiculturalism values found in a number of poetry verses. The poem illustrates the existence of racial differences and mutual respect for these differences. The message contained in the poem is in the second verse that is,: Yes, friends ... "They're colours; skin colours, ". The first verse describes the differences in race, ethnicity, and skin that distinguish between the same. The various skin colours possessed by humans are not a barrier to mutual respect, as explained in the last verse of the poem. The last verse of the poem explains about mutual respect with anyone. 


\subsection{A Poem by Josefin Candrika Tyas Pamikatsih, Elementary School Pangudi Luhur St Timotius Surakarta}

\section{Indonesiaku}

Berdiri kami di atas perbedaan,

Berbeda suku,

Berbeda budaya,

Berbeda agama,

Berbeda warna kulit,

Namun kita tetap satu

Wahai anak bangsa

Mari gandeng tangan bersama

Genggam erat Pancasila

Kibarkan sang saka dengan gagah

perkasa

Bangkitkan semangat persatuan

Singkirkan semua perbedaan

Junjung tinggi semangat kebangsaan

Untuk Indonesia kita tercinta
My Indonesia

We stand above the difference,

Different tribes,

Different cultures,

Different religions,

Different skin colours,

But we are still one

$O$ children of the nation

Let's join hands together

Hold on Pancasila

Fly away the Sang Saka up with pride

Raise the spirit of unity

Get rid of all the differences

Uphold the spirit of nationalism

For our beloved Indonesia

The poem entitled Indonesiaku above illustrates the diversity that exists in Indonesia. The diversity of religions, ethnicities, races, and cultures is not an excuse to blaspheme and hate each other among the nation's children. The last verse of the poem gives a message to understand and respect each other's differences and uphold unity. The indicator of multiculturalism found in the poem is mutual respect for diversity. It is this appreciation for the preservation that must be maintained and taught to the children so that it is embedded in the multiculturalism attitude from an early age.

\subsection{A Poem b Sabrina Febri W, State Elementary School Banciro Yogyakarta}

\section{Berbeda Tetap Satu}

Suku, agama, ras maupun budaya

Tidak akan menjadi penghalang

Untuk terus bersatu

Dalam Indonesia negeri kita Indonesia,

Memberi keragaman yang indah

Walau, berbeda tetapi satu

Seperti Bhinneka Tunggal Ika

Keberagaman menjadi semboyan kita

Menjadi penegak kemerdekaan

Berbeda warna kulit bukan menjadi penghalang

Karena kita bersatu untuk Indonesia
Different but One

Tribes, religions, races and cultures

Will not be a barrier

To keep uniting

In our country Indonesia,

Give beautiful diversity

Although we're different but one

Like Bhinneka Tunggal Ika

Diversity is our watchword

To be the upholder of independence

Different skin colours are not a barrier

Because we are uniteto Indonesia

The value of multiculturalism contained in the poem above is that Indonesia has differences in ethnicity, religion, race and culture. The poem illustrates the beauty of Indonesia's diversity. The value of multiculturalism depicted in the poem is respecting the diversity of Indonesia's ethnicity, race, religion, and culture. This multiculturalism-filled poem will certainly have a positive impact on the students, namely having mutual respect for each other. Considering that the elementary school students come from various tribes, religions, races and cultures, it is hoped that it can be a means of internalizing the values of multiculturalism from an early age. 


\subsection{A Poem by Fira Setyawati, State Elementary School Kotagede 4 Yogyakarta}

\begin{tabular}{ll}
\multicolumn{1}{c}{ Agama } & \multicolumn{1}{c}{ Religion } \\
Islam, Budha, Hindu, Kristen dan Katholik & Islam, Buddhism, Hinduism, Christianity and \\
Itu semua nama agama & Catholicism \\
Berbeda satu sama lain & They are all the names of religions \\
Percaya pada keyakinan & Different from one to each other \\
Ibadah yang berbeda & Believe in faith \\
Aturan yang berbeda & Different worships \\
Kita yang berbeda & Different rules \\
Berbeda tiap agama & We are different \\
Tapi kita satu & Different from each religion \\
Toleransi kita bersatu & Butwe are one \\
Bersatu menjadi kuat & Our tolerance is united \\
Bersatu menjadi Indonesia & United to be strong \\
\end{tabular}

The existence of religion is an important issue in the midst of the Indonesian socio-culture. Religious differences often trigger social conflicts. The occurrence of conflicts is caused by the inability of the people to bear tolerance among religious followers. This phenomenon must be addressed immediately to create religious diversity in this archipelago which is the nation's greatest asset in creating a safe, peaceful and tolerant society.

Religious conflicts should not occur in this country. This will adversely affect the younger generation in the future. Therefore, early multiculturalism education must be carried out. One effort to provide an understanding of the values of multiculturalism is through multiculturalism-filled children's poems. The poem by the student about "Religion" above illustrates that tolerance in religion must be upheld in the archipelago. This tolerance will later create harmony, comfort and safety in worship among others, and eradicate the existence of interfaith conflicts.

\section{CONCLUSION}

Based on the results of the analysis of several poems by the students, it can be concluded that the poems made by the elementary school students in Surakarta and Yogyakarta has contained the values of multiculturalism. The themes of the poems are religion, cultural diversity and mutual respect. The students' works show their understanding of multiculturalism, so that they are expected to appreciate differences in religion, ethnicity, skin colour, race, culture, respect among the same, and uphold a sense of unity.

\section{ACKNOWLEDGEMENT}

The researcher thanked LPDP BUDIDN as the research sponsor. Further thanks go to the rector of the University of Sarjanawiyata Tamansiswa Yogyakarta who has given permission for doctoral study. Thanks to the promoter, co-promoter 1, and co-promoter 2 who have guided in carrying out the research. The researcher also expressed his gratitude to the elementary schools in Surakarta and Yogyakarta for giving permission in conducting the research

\section{REFERENCES}

[1] R. K. Toha-Sarumpaet, Pedoman penelitian sastra anak. Jakarta: Pusat Bahasa, Kementerian Pendidikan Nasional, 2010.

[2] S. Anafiah, "Pemanfaatan Sastra Anak sebagai Media Penanaman Wawasan Multikultural," Trihayu J. Pendidik. Ke-SD-an, vol. 1, no. 1, pp. 10-15, 2014.

[3] Hasanuddin, Sastra Anak Kajian Tema, Amanat dan Teknik Penyampaian Cerita Anak Terbitan Surat Kabar (Children's Literature A Study of Theme, Message and Delivery technique of Children's Stories Issued by Newspapers). Bandung: Angkasa, 2015.

[4] R. Winarni, Kajian Sastra Anak (Children's Literature Study). Yogyakarta: Graha Ilmu, 2014. 
[5] T. Kachak and T. Blyznyuk, "Contemporary Ukrainian Literature for Children and Youth in the Context of Multiculturalism as an Educational Practice," J. Vasyl Stefanyk Precarpathian Natl. Univ., vol. 5, no. 1, Apr. 2018.

[6] A. Lubis, Pemikiran Kritis Kontemporer. Depok: PT Raja Grafindo Persada, 2016.

[7] S. Nugroho, Multikulturalisme Belajar Hidup Bersama dalam Perbedaan (Multiculturalism of Learning to Live Together in Differences. Jakarta: Indeks, 2011.

[8] T. Omar and W. Dan, "Multiculturalism And Malaysian Children's Literature In English," English Teach., vol. 36, pp. 1-19, 2017.

[9] P. McIver, "A Content Analysis of Multicultural Children's Books in the Republic of Korea and America," J. Lit. Art Stud., vol. 8, no. 1, 2018.

[10] Muliadi, "Nilai Multikultural Teks Puisi Husni Djamaluddin dalam Kajian Hermeneutika (Multicultural Values of Husni Djamaluddin's Poetry Text in Hermeneutic Study)," Postgraduate Program of Universitas Negeri Malang, 2014.

[11] D. Anwar, "Representasi Multikulturalisme Australia dalam Puisi Wogs Karya Ania Walwicz," Ling. Didakt. J. Bhs. dan Pembelajaran Bhs., vol. 1, no. 1, pp. 10-15, Dec. 2007.

[12] K. Klaus, Content Analysis an Introduction to its Methodology. California: Sage Publication, Inc, 2004.

[13] M. Miles and A. Huberman, Analisis Data Kualitatif (Qualitative Data Analysis). Jakarta: Jakarta: UIPress, 2009. 